\title{
The predictors of mortality in non-traumatic splenectomies
}

\author{
Arife SIMSEK
}

ABSTRACT - Background - There are quite a few studies examining prognostic factors in non-traumatic splenectomies compared to traumatic ones. Objective - This study aimed to evaluate the predictors of mortality in patients who underwent splenectomy for non-traumatic spleen diseases. Methods - Medical records of the patients, who had undergone total splenectomy for non-traumatic spleen diseases at a tertiary center between January 2009 and December 2019, were retrospectively reviewed. Exclusion criteria included patients younger than 18 years of age, partial splenectomies, splenectomies applied to facilitate surgery for malignancy on contiguous organs, and splenectomies performed during liver transplantation. Iatrogenic splenic injuries were regarded as trauma and these cases were also excluded. Results - The current study included 98 patients. Nine (9.2\%) patients died. In univariate analysis, age, the presence of hematological neoplasia, hematocrit, hemoglobin, white blood cell counts, neutrophil-to-lymphocyte ratio, indications for splenectomy, application of emergency surgery, surgical technique, and transfusion of blood components were all significantly associated with mortality. In multivariate analysis, the presence of hematological malignancy $[P=0.072$; OR $=7.17$; (CI: $0.386-61.56)]$, the application of emergency surgery $[P=0.035 ; \mathrm{OR}=8.33$; (CI: $1.165-59.595)]$ and leukocytosis $[P=0.057$; OR $=1.136$; (CI: $0.996-1.296)]$ were found to be positively associated with mortality. Conclusion - Hematologic neoplasia, emergency surgery, and leukocytosis were the independent predictors of mortality in patients, who were operated on for non-traumatic spleen diseases. A thorough preoperative evaluation, early therapeutic intervention, and advanced surgical techniques are important and can serve to minimize complications and mortality in case of inevitable splenectomy. Immunological research can provide new therapeutic opportunities that may impact positively on patients by minimizing morbidity and mortality.

HEADINGS - Splenectomy, mortality. Splenic diseases. Risk factors. Hematologic neoplasms. Emergencies. Leukocytosis.

\section{INTRODUCTION}

Although the Roman historian, Pliny, had reported splenectomies in the first century a.D., the first detailed description of a splenectomy was that performed by Adrian Zaccarelli in $1549^{(1)}$. While this surgery, which was carried out for non-traumatic spleen disease on a 24-year-old Greek woman with a giant spleen, splenectomies were mainly performed because of traumatic injury ${ }^{(1)}$. Mortality rates for splenectomies, which were performed before the 20th century, were high and many surgeons attributed adverse outcomes not to the removal of the spleen, but rather to the surgical procedure itself $^{(1)}$. Within 20 years, the mortality rate had fallen from $30 \%$ to $15 \%$ and splenectomy was recommended for all traumas (including iatrogenic trauma), any form of splenomegaly, hematological diseases, leukemias, lymphomas, abdominal neoplasms and even for the facilitation of surgery on contiguous organs ${ }^{(2,3)}$. Nowadays, recommendations for the complete removal of the spleen have become more restrictive due to its pivotal role in the immune system as the largest lymphoid organ in the human body, and for its role in hematopoiesis. Non-operative management of splenic trauma, minimally invasive surgery, and the increasing preference for partial splenectomy, in cases in which total splenectomy is not mandatory, are among significant trends in splenic surgery.

There are quite a few studies examining prognostic factors in non-traumatic splenectomies compared to traumatic ones ${ }^{(4-8)}$. This study aimed to evaluate the predictors of mortality in patients who underwent splenectomy for non-traumatic spleen diseases.

\section{METHODS}

Medical records of the patients, who had undergone total splenectomy for non-traumatic spleen diseases at a tertiary center between January 2009 and December 2019, were retrospectively reviewed. Exclusion criteria included patients younger than 18 years of age, partial splenectomies, splenectomies applied to facilitate surgery for malignancy on contiguous organs, and splenectomies performed during liver transplantation. Iatrogenic splenic injuries were regarded as trauma and these cases were also excluded.

The data included demographics, clinical findings, laboratory findings, radiological findings, and therapeutic interventions. The following characteristics were recorded:

- Demographics: age and gender;

- Clinical findings: comorbid factors (any systemic or hematological diseases, and hematological neoplasia), indications for splenectomy, postoperative hospital stay, perioperative complications, and mortality. Mortality was defined as any death that was considered to be a direct consequence of splenectomy;

- Laboratory findings: preoperative complete blood count (hematocrit, hemoglobin, white blood cell, and platelet) and inflammatory markers [neutrophil-to-lymphocyte ratio (NLR) and platelet-to-lymphocyte ratio (PLR)], which were calculated based on complete blood count results;

- Radiological findings: the largest diameter of the spleen based on ultrasonography and/or computerised tomography findings; and 
- Therapeutic interventions: application of emergency surgery, surgical technique (open or laparoscopic), and transfusion of blood components.

The study was conducted according to the principles as have set forth by the Helsinki Declaration of 1975. An approval from the Human Ethics Committee of Institution was obtained.

\section{Statistical analysis}

Data were analyzed using SPSS 17.0 for Windows. Continuous variables were presented as means with standard deviations (SDs), categorical variables were presented as numbers with percentages. A logistic model was set up to describe the relationship between mortality and variables associated with mortality. The Shapiro-Wilk test was used to analyze normality of the groups. The Student's $t$-test was used for continuous variables with normal distribution. The Mann-Whitney U-test was applied for non-normally distributed variables. The chi-squared test or Fisher's exact test was used for categorical variables. Significant variables were included in multivariate binary logistic regression analysis. A bivariate correlation test was used to determine whether there was a relationship between independent variables to be analyzed before multivariate binary logistic regression analysis. In multivariate binary logistic regression analysis, a backward stepwise method (Likelihood ratio) was used. The level of significance used at the entry of the variables was 0.05 , the level of significance used for removal was 0.1 . The level of significance used in testing the model in general was 0.05 .

\section{RESULTS}

The current study included 98 patients (62.2\% women), who underwent splenectomy for non-traumatic spleen diseases. The mean age was $44.14 \pm 16.19$ (range: $18-75$ ) years. Of 98 patients, 83 $(84.7 \%)$ had one or more systemic diseases including autoimmune hematological diseases $(n=48)$, hematological neoplasias $(n=16)$, hypertension $(n=14)$, diabetes mellitus $(n=9)$, coronary artery diseases $(n=2)$, congestive heart disease $(n=1)$, congenital heart disease $(n=1$, including atrial septal defect), pulmonary diseases $(n=3$, including one with chronic obstructive pulmonary disease, one with a pulmonary cyst that had been operated on, and one with pneumonia), hepatobiliary and/or portal venous system disorders $(n=10)$, end-stage renal diseases $(n=3)$, rheumatological diseases $[n=2$, including one with rheumatoid arthritis, and one with familial mediterranean fever (FMF)], neurologic disease $(n=1$, including multiple sclerosis), and hypothyroidism $(n=1)$. The mean length of the hospitalization was $7.02 \pm 6.97$ (range: $1-41$ ) days. The rates of mortality and morbidity were $9.2 \%$ and $33.7 \%$, respectively (TABLE 1 ).

The majority of the patients (49\%) were operated on for autoimmune hematological diseases, including immune thrombocytopenic purpura (ITP) $(n=45)$, autoimmune hemolytic anemia (AIHA) $(n=2)$ and hereditary spherocytosis (HS) $(n=1)$. Hematological neoplasias were found in 16 patients. However, hematological neoplasias were the primary indication for splenectomy in 12 of them. Half of the splenectomies, which were performed for infectious diseases were due to splenic hydatid cysts $(n=6)$. Of these, one patient had been treated with the PAIR (puncture, aspiration, injection, respiration) technique before. One patient with a splenic hydatid cyst presented with an allergic reaction due to the cyst rupturing. Six patients were operated on for splenic abscess, four of them were secondary to splenic infarct (one patient with Felty
Syndrome) and two were secondary to diffuse large B-cell lymphoma (DLBCL). One patient with splenic abscess had a previous history of percutaneous drainage. Nine patients were operated on for splenic neoplasia, and histopathologic results included benign epithelial cysts $(n=6)$, multiple cavernous hemangioma $(n=1)$, angiosarcoma $(n=1)$ and splenic infarct $(n=1)$. Nine patients underwent splenectomy with esophagogastric devascularization (The Shugiura procedure) for esophageal varices secondary to portal hyertension (PHT). Seven of them were the result of cirrhotic portal hypertension (CPHT), and two were the result of non-cirrhotic portal hypertension (NCPHT). Among eight patients, who were operated on for non-traumatic splenic rupture, three were on hemodialysis for ESRD, one had Von Willebrand Disease (VWD), one had chronic myeloproliferative disease (CMD), one had FMF, one had a septic splenic emboli secondary to infective endocarditis. One patient had a splenic rupture without any identifiable cause.

Emergency surgery was conducted in $14.3 \%$ of the cases (all with the open technique). It was conducted mainly for nontraumatic splenic rupture (eight cases) and infectious diseases (five cases including four splenic abscesses, and one splenic hydatid cyst). One patient with esophageal variceal bleeding also underwent emergency surgery. All of the surgeries, which were planned for autoimmune hematological diseases, were elective. All of the patients with hematological neoplasia, except three, who were operated on for non-traumatic splenic rupture $(n=2)$ and splenic abscess $(n=1)$, were operated on in an elective setting. The laparoscopic technique was preferred in 52 cases. However, six cases required open surgery due to splenomegaly $(n=3)$, bleeding $(n=2)$ and severe adhesion $(n=1)$ (conversion rate: $11.5 \%$ ). Thus, in $46(46.9 \%)$ cases, splenectomies were completed with the laparoscopic technique.

One or more of the following complications developed in 34 $(34.6 \%)$ patients: pulmonary complications $(n=20)$, subphrenic abscess $(n=12)$, portal venous system thrombosis (PVST) $(n=9)$, liver failure $(n=2)$, postoperative bleeding $(n=6)$, gastric injury $(n=1)$, gastric leakage $(n=1)$, pancreatic fistula $(n=1)$, pancreatitis $(n=2)$, fascial dehiscence $(n=4)$, acute inflammatory demyelinating polyneuropathy (AIDP) $(n=1)$, myocardial infarction $(n=1)$ and ischemic stroke $(n=1)$.

Pulmonary complications were the most common complications $(20.4 \%)$ including atelectasia $(n=12)$, pneumonia $(n=11)$, pleural effusion $(n=10)$ and pneumothorax secondary to diaphragm injury ( $n=3)$. PVST developed in $9.18 \%$ of cases. Three had PHT (two patients with CPHT and one patient with NCPHT). Two patients had AIHD (one had HS, the other had ITP with multiple sclerosis). One patient had splenic abscess with HT and DM, two patients had splenic neoplasia. One patient with FMF had nontraumatic splenic rupture. Two patients with PVST died due to liver faiure.

Nine $(9.2 \%)$ patients died. The rates of mortality in cases, operated on for AIHD, infectious diseases, splenic neoplasia, PHT, hematological neoplasia and non-traumatic splenic rupture, were $2.08 \%, 8.3 \%, 11.1 \%, 11.1 \%, 16.6 \%$, and $37.5 \%$, respectively. The mortality of the patients with hematologic neoplasia, independent of indications for surgery, was much higher (31.25\%). The mortality rate in emergency surgery was $35.7 \%$.

The characteristics of the deceased patients are presented in TABLE 2.

In univariate analysis, age, the presence of hematological neoplasia, hematocrit, hemoglobin, white blood cell counts, NLR, indications for splenectomy, application of emergency surgery, 
TABLE 1 . The univariate analysis associated with mortality.

\begin{tabular}{|c|c|c|c|c|}
\hline Characteristics & $\begin{array}{c}\text { Total } \\
(\mathrm{n}=98) \\
\text { mean } \pm \mathrm{SD} \text { or } \mathrm{n}(\%)\end{array}$ & $\begin{array}{c}\text { Mortality }(-) \\
(n=89) \\
\text { mean } \pm \text { SD or } n(\%)\end{array}$ & $\begin{array}{c}\text { Mortality }(+) \\
(n=9) \\
\text { mean } \pm \text { SD or } n(\%)\end{array}$ & $P$ \\
\hline Age (years) & $44.1 \pm 16.19$ & $42.96 \pm 15.9$ & $55.8 \pm 144$ & 0.018 \\
\hline \multicolumn{5}{|l|}{ Gender } \\
\hline Male & $37(37.8)$ & $31(34.8)$ & $6(66.7)$ & 0.078 \\
\hline Yes & $83(84.7)$ & $74(83.1)$ & $9(100)$ & \multirow{2}{*}{0.347} \\
\hline No & $15(15.3)$ & $15(16.9)$ & $(-)$ & \\
\hline \multicolumn{5}{|l|}{ Hematological disease } \\
\hline Yes & $16(16.3)$ & $11(12.4)$ & $5(55.6)$ & \multirow{2}{*}{0.005} \\
\hline No & $82(83.7)$ & $78(87.6)$ & $4(44.4)$ & \\
\hline \multicolumn{5}{|l|}{ Indications for splenectomy } \\
\hline Autoimmune hematological diseases & $48(49)$ & $47(52.8)$ & $1(11.1)$ & \multirow{5}{*}{0.043} \\
\hline Hematological neoplasia & $12(12.2)$ & $10(11.2)$ & $2(22.2)$ & \\
\hline Infectious diseases & $12(12.2)$ & $11(12.4)$ & $1(11.1)$ & \\
\hline Non-traumatic splenic rupture & $8(8.2)$ & $5(5.6)$ & $3(33.3)$ & \\
\hline Portal hypertension & $9(9.2)$ & $8(9)$ & $1(11.1)$ & \\
\hline Platelet value & $170.4 \pm 121.01$ & $163.3 \pm 109.59$ & $240.2 \pm 198.48$ & 0.319 \\
\hline White blood cell count & $13.4 \pm 22.2$ & $9.75 \pm 5.56$ & $49.52 \pm 63.59$ & 0.000 \\
\hline Neutrophil-to-lymphocyte ratio & $4.6 \pm 5.8$ & $3.91 \pm 3.94$ & $11.7 \pm 13.30$ & 0.033 \\
\hline Platelet-to-lymphocyte ratio & $114.1 \pm 137.1$ & $106.13 \pm 115.25$ & $192.85 \pm 272.7$ & 0.810 \\
\hline \multicolumn{5}{|l|}{ Application of emergency surgery } \\
\hline Yes & $14(14.3)$ & $9(10.1)$ & $5(55.6)$ & \multirow{2}{*}{0.003} \\
\hline No & $84(85.7)$ & $80(89.9)$ & $4(44.4)$ & \\
\hline \multicolumn{5}{|l|}{ Surgical technique } \\
\hline Open & $52(53.1)$ & $44(49.4)$ & $8(88.9)$ & \multirow{2}{*}{0.034} \\
\hline Laparoscopic & $46(46.9)$ & $45(50.6)$ & $1(11.1)$ & \\
\hline \multicolumn{5}{|l|}{ Transfusion of blood components } \\
\hline Yes & $43(43.9)$ & $35(39.3)$ & $8(88.9)$ & \multirow{2}{*}{0.009} \\
\hline No & $55(56.1)$ & $54(60.7)$ & $1(11.1)$ & \\
\hline
\end{tabular}


TABLE 2. Characteristics of the deceased patients.

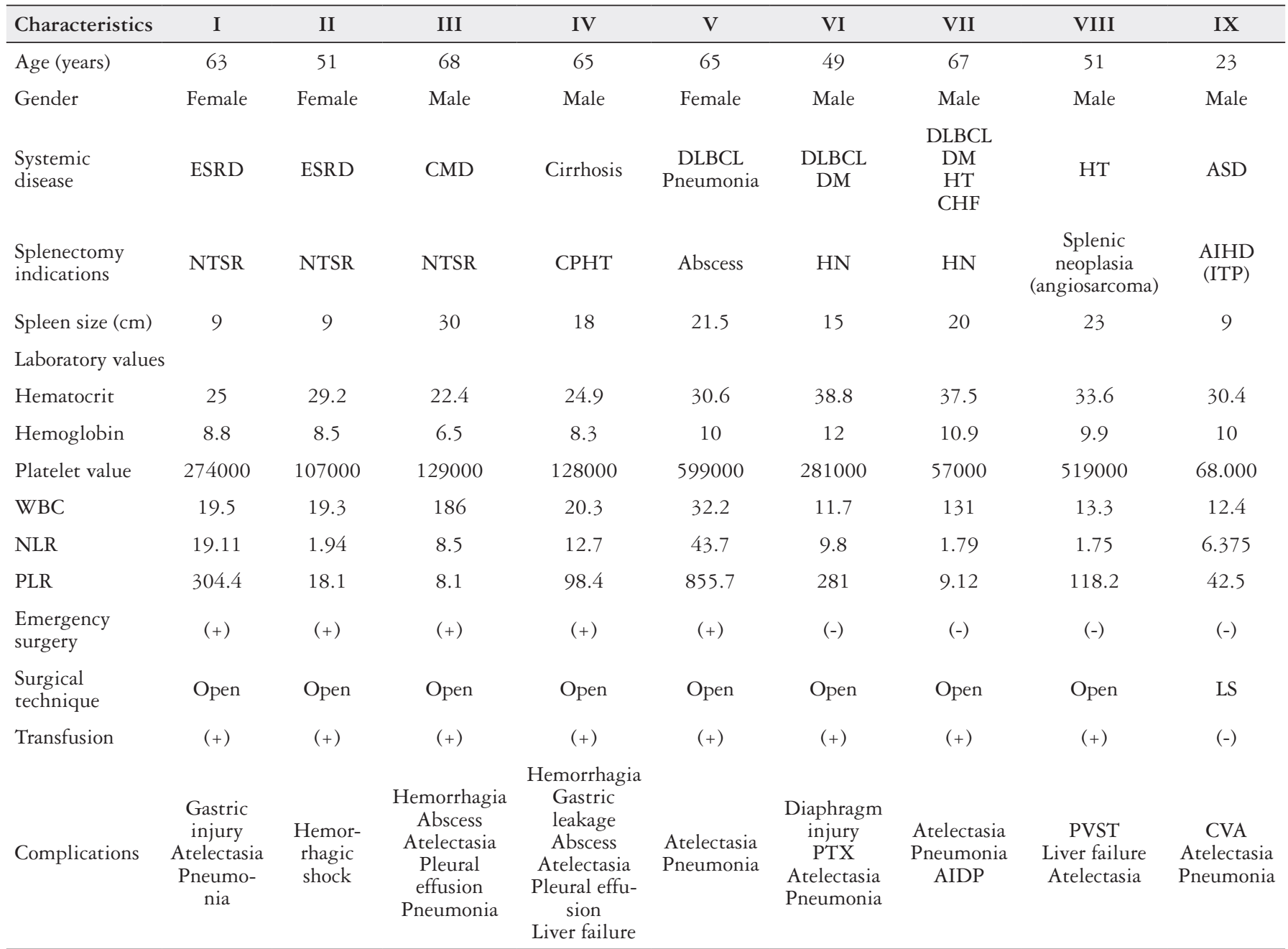

WBC: white blood cell, NLR: neutrophil to lymphocyte ratio, PRL: platelet to lymphocyte ratio, ESRD: end stage renal disease, CMD: chronic myeloproliferative disease, DLBCL: diffuse large B-cell lymphoma, DM: diabetes mellitus, HT: hypertension, CHF: congestive heart failure, PVST: portal venous system thrombosis, PTX: pneumothorax, NTSR: non-traumatic splenic rupture, CPHT: cirrhotic portal hypertension, HN: hematological neoplasia AIDP: acute inflammatory demyelinating polyneuropathies LS: laparoscopic surgery.

surgical technique, and transfusion of blood components were all significantly associated with mortality (TABLE 1$)$. In multivariate analysis, the presence of hematological malignancy $[P=0.072$; $\mathrm{OR}=7.17$; (CI: $0.386-61.56)]$, the application of emergency surgery $[P=0.035 ; \mathrm{OR}=8.33$; $(\mathrm{CI}: 1,165-59.595)]$ and leukocytosis $[P=0.057 ; \mathrm{OR}=1.136$; $(\mathrm{CI}: 0.996-1.296)]$ were found to be positively associated with mortality. The characteristics of the patients with hematological neoplasias and patients treated by emergency surgery are presented in TABLE 3 and TABLE 4, respectively.

\section{DISCUSSION}

The majority of elective splenic surgery is performed for diagnosis, palliation, or the definitive management of hematological disorders as in the current study.

In the current study, the mortality rate was $9.2 \%$, which was consistent with the rates $(6-9 \%)$ reported in the literature ${ }^{(4-8)}$. Hematologic neoplasia, emergency surgery, and leukocytosis were the independent predictors of mortality.
Patients with hematological neoplasia become less well after splenectomy than those with autoimmune hemolytic disorders ${ }^{(9)}$. According to the current study, patients with hematologic neoplasia had a 7.17-fold greater mortality. The increased mortality may be attributed to the subgroup of patients included in the study and the underlying disease itself. Hematological neoplasias were found in $19.5 \%$ of the cases, predominantly in older patients. Elderly patients with hematological disorders may be at an increased risk of surgical morbidity, as concluded in previous studies ${ }^{(4,5,8,10,11)}$. Hematocrit and hemoglobin values were significantly lower in cases with hematological neoplasias than in cases without. Anemia itself may contribute to clinical deterioration and result in an increased need for transfusion compared to patients without hematologic neoplasias.

Emergency cases had an 8.33-fold greater mortality rate compared to that of those who underwent elective surgery. It was not surprising that hematocrit, hemoglobin and platelet values were all lower in patients treated by emergency surgery than those in patients treated by elective surgery, while the white blood cell count, 
TABLE 3. The characteristics of the patients with hematological neoplasia.

\begin{tabular}{|c|c|c|c|}
\hline Characteristics & $\begin{array}{c}\text { Hematological } \\
\text { neoplasia }(-) \\
(n=82) \\
\text { mean } \pm \text { SD or } \\
n(\%)\end{array}$ & $\begin{array}{c}\text { Hematological } \\
\text { neoplasia }(+) \\
(n=16) \\
\text { mean } \pm \text { SD or } \\
n(\%)\end{array}$ & $P$ \\
\hline Age (years) & $41.23 \pm 15.4$ & $59.06 \pm 11.01$ & 0.000 \\
\hline \multicolumn{4}{|l|}{ Gender } \\
\hline Male & $27(32.9)$ & $10(62.5)$ & \multirow{2}{*}{0.026} \\
\hline Female & $55(67.1)$ & $6(37.5)$ & \\
\hline
\end{tabular}

Indications for splenectomy

\begin{tabular}{|c|c|c|c|}
\hline $\begin{array}{l}\text { Autoimmune } \\
\text { hematological } \\
\text { diseases }\end{array}$ & $48(58.5)$ & $(-)$ & \\
\hline $\begin{array}{l}\text { Hematological } \\
\text { neoplasia }\end{array}$ & $(-)$ & $12(75)$ & \\
\hline Infectious diseases & $10(12.2)$ & $2(12.5)$ & 0.000 \\
\hline $\begin{array}{l}\text { Non-traumatic } \\
\text { splenic rupture }\end{array}$ & $7(8.5)$ & $1(6.3)$ & \\
\hline $\begin{array}{l}\text { Portal } \\
\text { hypertension }\end{array}$ & $9(11)$ & $(-)$ & \\
\hline Splenic neoplasia & $8(9.8)$ & $1(6.3)$ & \\
\hline $\begin{array}{l}\text { Largest diameter of } \\
\text { the spleen }(\mathrm{cm})\end{array}$ & $13.1 \pm 4.7$ & $20.9 \pm 7.47$ & 0.000 \\
\hline \multicolumn{4}{|l|}{ Laboratory findings } \\
\hline Hematocrit value & $37.02 \pm 7.06$ & $30.38 \pm 6.88$ & 0.001 \\
\hline Hemoglobin value & $12.15 \pm 2.45$ & $9.78 \pm 2.24$ & 0.001 \\
\hline Platelet value & $167.07 \pm 108.1$ & $187.5 \pm 176.6$ & 0.848 \\
\hline $\begin{array}{l}\text { White blood cell } \\
\text { count }\end{array}$ & $10.3 \pm 5.14$ & $28.9 \pm 52.4$ & 0.784 \\
\hline $\begin{array}{l}\text { Neutrophil-to- } \\
\text { lymphocyte ratio }\end{array}$ & $4.3 \pm 4.34$ & $6.32 \pm 10.6$ & 0.492 \\
\hline $\begin{array}{l}\text { Platelet-to- } \\
\text { lymphocyte ratio }\end{array}$ & $100.13 \pm 97$ & $15.68 \pm 253.27$ & 0.384 \\
\hline
\end{tabular}

Application of emergency surgery

$\begin{array}{cccc}\text { Yes } & 11(13.4) & 3(18.8) & \\ \text { No } & 71(86.6) & 13(81.3) & 0.695\end{array}$

Surgical technique

$\begin{array}{ll}\text { Open } & 36(43.9) \\ \text { Laparoscopic } & 46(56.1)\end{array}$

$16(100)$

$(-)$

0.000

Transfusion of blood components

$\begin{array}{cccc}\text { Yes } & 30(36.6) & 13(81.3) & 0.001 \\ \text { No } & 52(63.4) & 3(18.8) & \end{array}$

Mortality

\begin{tabular}{cccc} 
Yes & $4(4.9)$ & $5(31.3)$ & 0.005 \\
No & $78(95.1)$ & $11(68.8)$ & \\
\hline
\end{tabular}

SD: standard deviation.
TABLE 4 . The characteristics of the surgical planning and scheduling.

\begin{tabular}{|c|c|c|c|}
\hline Characteristics & $\begin{array}{c}\text { Elective surgery } \\
\text { (n: 84) } \\
\text { Mean } \pm \text { SD or } \\
n(\%)\end{array}$ & $\begin{array}{c}\text { Emergency } \\
\text { surgery } \\
(\mathrm{n}: 14) \\
\text { Mean } \pm \text { SD or } \\
n(\%)\end{array}$ & $P$ \\
\hline Age (years) & $42.04 \pm 15.84$ & $56.71 \pm 12.49$ & 0.002 \\
\hline \multicolumn{4}{|l|}{ Gender } \\
\hline Male & $29(34.5)$ & $8(57.1)$ & \multirow{2}{*}{0.106} \\
\hline Female & $55(65.5)$ & $6(42.9)$ & \\
\hline \multicolumn{4}{|c|}{ Systemic disease (any) } \\
\hline Yes & $72(85.7)$ & $11(78.6)$ & \multirow{2}{*}{0.364} \\
\hline No & $12(14.3)$ & $3(21.4)$ & \\
\hline \multicolumn{4}{|c|}{ Hematological disease } \\
\hline Yes & $61(72.6)$ & $4(28.6)$ & \multirow{2}{*}{0.002} \\
\hline No & $23(27.4)$ & $10(71.4)$ & \\
\hline \multicolumn{4}{|c|}{ Hematological neoplasia } \\
\hline Yes & $13(15.5)$ & $3(21.4)$ & \multirow{2}{*}{0.409} \\
\hline No & $71(84.5)$ & $11(78.6)$ & \\
\hline
\end{tabular}

Indications for splenectomy

\begin{tabular}{|c|c|c|c|}
\hline $\begin{array}{l}\text { Autoimmune } \\
\text { hematological } \\
\text { diseases }\end{array}$ & $48(57.1)$ & $(-)$ & \multirow{5}{*}{0.003} \\
\hline $\begin{array}{l}\text { Hematological } \\
\text { neoplasia }\end{array}$ & $12(14.3)$ & $(-)$ & \\
\hline Infectious diseases & $7(8.3)$ & $5(35.7)$ & \\
\hline $\begin{array}{l}\text { Non-traumatic } \\
\text { splenic rupture }\end{array}$ & $(-)$ & $8(57.1)$ & \\
\hline $\begin{array}{l}\text { Portal } \\
\text { hypertension }\end{array}$ & $8(9.5)$ & $1(7.1)$ & \\
\hline Splenic neoplasia & $9(10.7)$ & $(-)$ & \\
\hline $\begin{array}{l}\text { argest diameter of } \\
\text { he spleen }(\mathrm{cm})\end{array}$ & $14.46 \pm 6.02$ & $13.96 \pm 5.89$ & 0.818 \\
\hline \multicolumn{4}{|l|}{ aboratory findings } \\
\hline Hematocrit value & $36.58 \pm 7.03$ & $32.09 \pm 8.71$ & 0.035 \\
\hline Hemoglobin value & $11.98 \pm 2.4$ & $10.48 \pm 3.19$ & 0.043 \\
\hline Platelet value & $288.9 \pm 148.88$ & $150.66 \pm 104.30$ & 0.001 \\
\hline $\begin{array}{l}\text { White blood cell } \\
\text { count }\end{array}$ & $10.9 \pm 14.34$ & $28.42 \pm 45.77$ & 0.000 \\
\hline $\begin{array}{l}\text { Neutrophil-to- } \\
\text { lymphocyte ratio }\end{array}$ & $3.35 \pm 2.79$ & $12.31 \pm 11.35$ & 0.001 \\
\hline $\begin{array}{l}\text { Platelet-to- } \\
\text { lymphocyte ratio }\end{array}$ & $87.76 \pm 75.84$ & $272.1 \pm 268.93$ & 0.019 \\
\hline \multicolumn{4}{|l|}{ urgical technique } \\
\hline Open & $38(45.2)$ & $14(100)$ & \multirow{2}{*}{0.000} \\
\hline Laparoscopic & $46(54.8)$ & $(-)$ & \\
\hline
\end{tabular}

Transfusion of blood components

\begin{tabular}{cccc} 
Yes & $30(35.7)$ & $13(92.9)$ & 0.000 \\
No & $54(64.3)$ & $1(7.1)$ & \\
Mortality & & & \\
Yes & $4(4.8)$ & $5(35.7)$ & 0.003 \\
No & $80(95.2)$ & $9(64.3)$ & \\
\hline
\end{tabular}

SD: standard deviation. 
NLR and PLR were higher. Bleeding due to splenic rupture and underlying infection may cause anemia and leucocytosis in patients, who undergo emergency surgery. The low platelet count may be a reflection of several factors such as splenic sequestration, blood loss, uremia, heparin use, and sepsis in those patients.

In the current study, leukocytosis was among the independent predictors of mortality. It may be a reflection of an altered immunity in those patients. The immune system plays a critical role in many processes involving chronic diseases and neoplasia. For many diseases, this altered immune activity is characterized as inflammatory dysregulation $^{(12)}$. Furthermore, neoplasia itself triggers chronic inflammation ${ }^{(13)}$. Along with hematological neoplasias, chronic diseases, non-hematological malignancy, and splenic abscess itself may have been responsible for leukocytosis in the deceased patients. In patients with chronic disease and neoplasia, the microorganisms easily thwart the immune system's defenses. Considering the pivotal role of the spleen in the immune system, it is not surprising that infections lead to mortality in such patients. Despite recognition of the critical role of inflammatory dysregulation in chronic diseases and neoplasms, there are many areas of the immune mechanism that remain unelucidated. Increasing knowledge of the unique role of the spleen has attracted attention with respect to the development of therapeutic alternatives to total splenectomy.

Several studies reported pulmonary complications as the most common complications after splenectomy, occurring in nearly $30 \%$ of cases $^{(7-9)}$. Furthermore, a study concluded that pneumonia was the only independent factor for mortality in patients, who had undergone splenectomy for non-traumatic spleen disease ${ }^{(8)}$. According to the current study, pulmonary complications were the most common complications, and developed in all of the deceased patients.

Postoperative bleeding occurs mostly when splenectomy is performed for hypersplenism, particularly in patients with thrombocytopenia ${ }^{(9)}$. In the current study, postoperative bleeding developed in $6.1 \%$ of the cases. Of the deceased patients, two had hypersplenism with thrombocytopenia, which resulted in postoperative bleeding.

Gastric injury and leakage are rare and preventable complications of splenic surgery ${ }^{(9)}$. In the current study, it occurred in two of the deceased patients leading to intraabdominal abscess in one, who had undergone the Shugiura procedure. In that patient, complicated emergency surgery led to decompensated cirrhosis.

Acute inflammatory demyelinating polyneuropathy is one form of acquired demyelinating polyneuropathy, which are inflammatory-demyelinating diseases of the peripheral nervous system, and have an immunologic pathogenesis ${ }^{(14)}$. A preceding event is most commonly a respiratory tract infection or gastroenteritis $^{(14)}$. They are also associated with other infections (EBV, CMV, toxoplasmosis), malignant diseases including Hodgkin's disease and non-Hodgkin's lymphoma, and surgery ${ }^{(14)}$. Along with peripheral nerves, the muscles that control breathing and the bulbus may be affected, resulting in respiratory failure and pneumonia. Autonomic dysfunction may cause sudden death, likely related to cardiac dysrhythmia ${ }^{(14)}$. A 67-year-old male, who had undergone splenectomy for hematological neoplasia, died due to AIDP and pneumonia.

Portal venous system thrombosis is a lethal disease char- acterized by the development of thrombosis within the portal vein, mesenteric vein, and splenic vein ${ }^{(15)}$. It has a wide spectrum of clinical manifestations that range from a partial obstruction of the vessel to a complete obstruction of portal venous blood flow, leading to hepatic decompensation, variceal bleeding and intestinal infarction ${ }^{(16)}$. Its incidence after splenectomy varies from $0 \%$ to $50 \%$, depending upon the heterogeneity of the cases included $^{(15)}$. It has been reported most commonly in patients who had undergone splenectomy for $\mathrm{CMDs}^{(9,17)}$. Splenomegaly, hypercoagulability and surgical trauma to the splenic vein may be the predisposing factors for clot formation at the hilum of the spleen $^{(9)}$. In the current study, PVST developed in 9 cases following splenectomy, and two patients died due to liver failure. PVST is a well-known complication that occurs during the natural course of liver cirrhosis ${ }^{(16,18-20)}$. In our patients, only three had previous PHT. One of the deceased patients, who had developed liver failure had a CPHT, the other had not. A 51-year-old male, who underwent splenectomy for splenic neoplasia (angiosarcoma), died due to sepsis and hepatic decompensation secondary to PVST. As far as we know, this was the first case reported, in which PSVT after splenectomy, led to liver decompansation without predisposing liver disease.

Although patients with ITP have a low platelet count with a tendency to bleeding, they occasionally develop venous and/or arterial thromboembolic events by a mechanism, which has not been fully elucidated. In a retrospective study, the incidence of venous, arterial and combined thromboembolic events was reported as $2.9 \%, 4.1 \%$, and $6.1 \%$, respectively ${ }^{(21)}$. In the current study, thromboembolic events were developed in three patients with ITP [PVT $(n=1)$, myocardial infarction $(n=1)$, ischemic stroke $(n=1)]$. The literature usually focuses on case series (from one to seven cases; in 13 studies, there was a total of 19 cases) including ITP with ischemic stroke ${ }^{(22)}$. They reported good outcomes in all cases, except for one ${ }^{(22)}$. Of those cases, $57.9 \%$ had some of the conventional risk factors for stroke ${ }^{(22)}$, as in our patient with ASD. Unfortunately, a 23-year-old male with ITP experienced an ischemic stroke following splenectomy and died. The surgery itself may exacerbate the underlying risk conditions.

Retrospective design and small case numbers were limitations of this study.

\section{CONCLUSION}

Hematologic neoplasia, emergency surgery and leukocytosis were the independent predictors of mortality in patients, who were operated on for non-traumatic spleen diseases. A thorough preoperative evaluation, early therapeutic intervention, and advanced surgical techniques are important and can serve to minimize complications and mortality in case of inevitable splenectomy. Immunological research can provide new therapeutic opportunities that may impact positively on patients by minimizing morbidity and mortality.

\section{Author's contribution}

Simsek A: conception and design; analysis and interpretation of the data; drafting of the article; critical revision of the article for important intellectual content; final approval of the article. 
Simsek A. Os preditores da mortalidade em esplenectomias não traumáticas. Arq Gastroenterol. 2020;57(4):459-65.

RESUMO - Contexto - Há alguns estudos que examinam fatores prognósticos em esplenectomias não traumáticas em comparação com os traumáticos. Objetivo - Este estudo teve como objetivo avaliar os preditores de mortalidade em pacientes submetidos à esplenectomia para doenças do baço não traumático. Métodos - Os prontuários dos pacientes, submetidos à esplenectomia total não traumática para doenças do baço em um centro terciário entre janeiro de 2009 e dezembro de 2019, foram revisados retrospectivamente. Os critérios de exclusão incluíram pacientes menores de 18 anos, esplenectomias parciais, esplenectomias aplicadas para facilitar a cirurgia para a malignidade em órgãos contíguos e esplenectomias realizadas durante o transplante hepático. As lesões esplênicas iatrogênicas foram consideradas trauma e esses casos também foram excluídos. Resultados - O presente estudo incluiu 98 pacientes. Nove $(9,2 \%)$ pacientes morreram. Na análise univariada, idade, presença de neoplasia hematológica, hematócrito, hemoglobina, contagem de glóbulos brancos, razão entre neutrófilos-linfócitos, indicações de esplenectomia, aplicação de cirurgia de emergência, técnica cirúrgica e transfusão de componentes sanguíneos foram significativamente associadas à mortalidade. Na análise multivariada, a presença de malignidade hematológica $[P=0,072 ; \mathrm{OR}=7,17$; (IC: 0,386-61,56)], aplicação de cirurgia de emergência $[P=0,035 ;$ OR=8,33; (IC: $1,165-59,595)]$ e leucocitose $[P=0,057 ; \mathrm{OR}=1,136 ;(\mathrm{IC}: 0,996-1,296)]$ verificou-se que estão positivamente associados à mortalidade. Conclusão- Neoplasia hematológica, cirurgia de emergência e leucocitose foram os preditores independentes da mortalidade em pacientes, operados por doenças não traumáticas do baço. Uma avaliação pré-operatória minuciosa, intervenção terapêutica precoce e técnicas cirúrgicas avançadas são importantes e podem servir para minimizar complicações e mortalidade em caso de inevitável esplenectomia. Pesquisas imunológicas podem fornecer novas oportunidades terapêuticas que podem impactar positivamente nos pacientes, minimizando a morbidade e a mortalidade.

DESCRITORES - Esplenectomia, mortalidade. Esplenopatias. Fatores de risco. Neoplasias hematológicas. Emergências. Leucocitose.

\section{REFERENCES}

1. Petroianu A. Historical aspects of the spleen and splenic surgeries. In: Petroianu A (editor): The spleen. Bentham Science Publishers: Brazil; 2011, p. 3-19.

2. Delpero JR, Houvenaeghel G, Gastaut JA, Orsoni P, Blache JL, Guerinel G, et al Splenectomy for hypersplenism in chronic lymphocytic leukemia and malignant non-Hodgkin's lymphoma. Br J Surg. 1990;77:443-49.

3. Coco D, Leanza S. Indications for Surgery in Non-Traumatic Spleen Disease. Open Access Maced J Med Sci. 2019;7:2958-60.

4. Aksnes J, Abdelnoor M, Mathisen O. Risk factors associated with mortality and morbidity after elective splenectomy. Eur J Surg. 1995;161:253-8.

5. Al Harbi M. Predictors for morbidity and mortality following non-traumatic splenectomy at the University Hospital, Jeddah, Saudi Arabia. Int Surg. 2000;85:317-21.

6. Arnoletti JP, Karam J, Brodsky J. Early postoperative complications of splenectomy for hematologic disease. Am J Clin Oncol. 1999;22:114-8.

7. Horowitz J, Smith JL, Weber TK, Rodriguez-Bigas MA, Petrelli NJ. Postoperative complications after splenectomy for hematologic malignancies. Ann Surg. 1996;223:290-6.

8. Gianchandani Moorjani R, Marchena-Gomez J, Casimiro-Perez J, Roque-Castellano C, Ramirez-Felipe J. Morbidity-and mortality-related prognostic factors of nontraumatic splenectomies. Asian J Surg. 2014;37:73-9.

9. Scott-Conner CEH, Mancino AT, Lawrence J. Surgery of the Spleen. In: Bowdler AJ (editor): The complete spleen structure, function, and clinical disorders. 2nd ed. Springer Science + Business Media: New York; 2002, p. 281-315.

10. Rosen M, Brody F, Walsh RM, Tarnoff M, Malm J, Ponsky J. Outcome of laparoscopic splenectomy based on hematologic indication. Surg Endosc. 2002;16:272-9.

11. Ziemski JM, Rudowski WJ, Jaskowiak W, Rusiniak L, Scharf R. Evaluation of early postsplenectomy complications. Surg Gynecol Obstet. 1987;165:507-14.

12. Zhong J, Shi G. Editorial: Regulation of Inflammation in Chronic Disease. Front Immunol. 2019;10:737.
13. Roxburgh CS, McMillan DC. Role of systemic inflammatory response in predicting survival in patients with primary operable cancer. FutureOncol. 2010;6:149-63.

14. Albers JW, Kelly JJ Jr. Acquired inflammatory demyelinating polyneuropathies; clinical and electrodiagnostic features. Muscle Nerve. 1989;12:435-51.

15. Qi X, Bai M, Guo X, Fan D. Pharmacologic Prophylaxis of Portal Venous System Thrombosis after Splenectomy: A Meta-Analysis. Gastroenterology Research and Practice. 2014. doi: 10.1155/2014/292689.

16. Faccia M, Ainora ME, Ponziani FR, Riccardi L, Garcovich M, Gasbarrini A, et al. Portal vein thrombosis in cirrhosis: Why a well-known complication is still matter of debate. World J Gastroenterol. 2019;25:4437-51.

17. Winslow ER, Brunt LM, Drebin JA, Soper NJ, Klingensmith ME. Portal vein thrombosis after splenectomy. Am J Surg. 2002;184:631-5; discussion 635-636.

18. Amitrano L, Guardascione MA, Brancaccio V, Margaglione M, Manguso F, Iannaccone L, et al. Risk factors and clinical presentation of portal vein thrombosis in patients with liver cirrhosis. J Hepatol. 2004;40:736-41.

19. Bagheri Lankarani K, Homayon K, Motevalli D, Heidari ST, Alavian SM, Malek-Hosseini SA. Risk factors for portal vein thrombosis in patients with cirrhosis awaiting liver transplantation in Shiraz, Iran. Hepat Mon. 2015;15: e26407.

20. Qi X, Han G, Ye C, Zhang Y, Dai J, Peng Y, et al. Splenectomy causes 10-fold increased risk of portal venous system thrombosis in liver cirrhosis patients. Med Sci Monit. 2016;22:2528-50.

21. Sarpatwari A, Bennett D, Logie JW, Shukla A, Beach KJ, Newland AC, et al. Thromboembolic events among adult patients with primary immune thrombocytopenia in the United Kingdom General Practice Research Database. Haematologica. 2010;95:1167-75.

22. Zhao H, Lian Y, Zhang H, Xie N, Gao Y, Wang Z, et al. Ischemic stroke associated with immune thrombocytopenia. J Thromb Thrombolysis. 2015;40:156-60. 